Ao exame clínico foram constatadas hipertermia, emagrecimento, mucosas sub ictéricas, leve desidratação $\mathrm{e}$ pequena sensibilidade à palpação em região lombar. Os exames hematológicos revelaram anemia e leucocitose. Na urocultura, realizada através de coleta de urina por cistocentese, verificou-se a presença de Edwarsiella sp. $\mathrm{O}$ animal foi submetido a exame ultra-sonográfico abdominal que revelou presença de três estruturas circulares, cavitárias, preenchidas por conteúdo líquido hipo/anecóico, indicando alta celularidade, uma em pólo cranial e duas em pólo caudal de rim direito (abscessos renais). Após a observaçào dessas lesões realizou-se a drenagem ecodirigida, obtendo-se material purulento e isolandose, da cultura do mesmo, a bactéria Escherichia coli.Foram instituidas fluidoterapia (durante 36 dias) e antibioticoterapia (50 dias), coerentes com os resultados obtidos nas culturas da urina e do material do abscesso renal. Exames ultra-sonográficos seriados de controle foram realizados a cada 20 dias aproximadamente e realizadas mais duas drenagens percutâneas dos abscessos renais. Em cada uma das três drenagens o material dos abscessos mudou de aspecto. Estas foram realizadas com o paciente sob anestesia geral, no $1^{\circ}, 10^{\circ}$ e $36^{\circ}$ dias após início do tratamento. Após 50 dias de terapêutica, o animal ganhou peso progressivamente, melhorando sensivelmente o estado geral (ausência de anemia, desidrataçào e hipertermia). No último controle ultra-sonográfico realizado, após 30 dias de terapêutica suspensa, não foram detectadas áreas cavitárias $\mathrm{em}$ rim direito. Todos os procedimentos foram realizados após o consentimento informado por parte do proprietário. O presente trabalho demonstra a eficácia da drenagem de abscesso renal guiada por ultra-som, aliada a antibioticoterapia oral intensiva, sem a necessidade de nefrectomia e com a preservação do parênquima renal.

\title{
39 - Estudo radiográfico das lesões ósseas agressivas na espécie canina
}

1- M.V. Residente do Hospital Veterinário da Universidade de Santo Amaro, São Paulo-SP

2- Professora Assistente da Disciplina de Diagnóstico por Imagem da Faculdade de Medicina Veterinária da Universidade de Santo Amaro, São Paulo-SP

$\mathrm{Na}$ tentativa de interpretar uma lesão óssea, é possível sugerir que alterações radiográficas pareçam "agressivas", "semi-agressivas" ou "nào agressivas". Isto não é sinônimo de alteraçōes malignas ou benignas, mas está relacionada com a taxa de crescimento da alteração patológica e o quanto o tecido ósseo marginal teve oportunidade de responder a esta lesão. As lesões ósseas neoplásicas e infecciosas têm tipicamente aspecto radiográfico agressivo. É impossivel estabelecer uma distinçào definitiva entre neoplasia e infecção óssea por avaliação radiográfica isoladamente. Contudo, somando os aspectos radiográficos da lesão óssea, à história clínica, aos achados clínicos e laboratoriais, torna-se possível a diferenciação entre doença óssea neoplásica e doença óssea infecciosa com exatidào. A causa mais comum de lesão óssea agressiva solitária é o tumor ósseo primário. O osteossarcoma é o tumor ósseo primário mais freqüente na espécie canina, principalmente em raças grandes e gigantes e em animais com mais de seis anos de idade, com localização mais comum em região metafisária de ossos longos. Foram avaliadas as radiografias do sistema músculo-esquelético de animais da espécie canina, atendidos no Hospital Veterinário da Universidade de Santo Amaro, no periodo de julho de 1999 a julho de 2002, com o intuito de analisar os aspectos radiográficos observados nas lesões ósseas agressivas, incluindo localização e distribuição, avaliar a frequência destes casos em nosso meio e relatar incidencia quanto as raças, sexo e idade dos animais. As projeçòes radiográficas realizadas e os aspectos radiográficos observados quanto ao padrão de lesão, extensão, margem, localização e distribuição foram anotados em fichas individuais bem como informações adicionais, como ocorrência de alterações em outros sistemas. Neste periodo, foram examinados 44 cães com comprometimento de 53 ossos, sendo que $48 \operatorname{ossos}(90,6 \%)$ apresentaram lesão do tipo agressiva e 5 ossos $(9,4 \%)$ foram considerados 
portadores de lesão semi-agressiva. A lesão óssea monostótica foi a mais freqüente $(86,3 \%)$ sendo o padrào radiográfico osteolítico predominante em 40 casos $(75,5 \%)$. Comprometimento de ossos longos foi observado em 36 exames $(67,9 \%)$. A localização metáfisária foi a mais freqüente, vista em 28 casos $(77,7 \%)$, destacando-se a metáfise distal do rádio $(34.5 \%)$ e a metáfise proximal do úmero $(32,4 \%)$. O acometimento de cães com idade entre 5 a 10 anos foi o mais freqüente $(61,4 \%)$, sendo que os animais de raças puras foram os mais acometidos (70,5\%), destacando-se Dogue Alemão (13,6\%), Filla Brasileiro $(11,4 \%)$ e Doberman $(9.1 \%)$. Dos 44 animais, 23 eram machos e 21 fêmeas. Dentre as alteraçōes radiográficas encontradas a ocorrência de fratura patológica foi vista em 11 casos $(24,5 \%)$. Com tal estudo pudemos concluir que o exame radiográfico constitui método importante para a detecção de lesão óssea agressiva, sendo estas freqüentes em nosso meio. Para definiçào de diagnóstico das lesões ósseas agressivas consideramos fundamental a realização de biópsias para análise histopatológica, bem como, a avaliação radiográfica do tórax e ultra-sonográfica do abdômen para pesquisas de metástases.

\section{0 - Estudo radiográfico de lesões pulmonares na espécie canina}

1- M.V. Residente do Hospital Veterinário da Universidade de Santo Amaro, São Paulo-SP

2- Professora Assistente da Disciplina de Diagnóstico por Imagem da Faculdade de Medicina Veterinária da Universidade de Santo Amaro, São Paulo-SP

A avaliaçào radiográfica das doenças pulmonares em pequenos animais está amparada por uma série de quadros patológicos. Essa relaçào é baseada nos diferentes quadros anatômicos radiográficos quanto as diferentes estruturas anatômicas dos pulmões são afetadas. $\mathrm{O}$ quadro relacionado ao diagnóstico está sendo utilizado por radiologistas por muitos anos e foi primeiramente utilizado em medicina veterinária em 1968. Quando esclarecidos esses quadros são extremamente úteis na formulação de diagnósticos diferenciais. Há também condições patológicas dos pulmões que resultam em quadros mistos ou quadros que modificam-se de um tipo para outro num período de tempo. A correlação dos achados radiográficos com exame clínico e achados laboratoriais é imperativo para alcançar o diagnóstico correto. Foram avaliadas as radiografias do tórax de 460 animais da espécie canina, atendidos no Hospital Veterinário da Universidade de Santo Amaro, no período de janeiro de 1999 a dezembro de 2001, com o objetivo de analisar os aspectos radiográficos observados nas lesões pulmonares, incluindo localização e distribuiçào, e analisar a frequêencia destes casos em nosso meio. Para melhor avaliação dos campos pulmonares os exames radiográficos foram constituídos das projeçōes laterais (decúbitos direito e esquerdo) e da projeção ventrodorsal. Os aspectos radiográficos observados, quanto aos padròes de lesão, extensão, localização e distribuição, foram anotados em fichas individuais bem como informações adicionais, como a ocorrência de alterações outras em cavidade torácica. Neste estudo observamos 91 casos $(19.8 \%)$ de lesões pulmonares; destes 34 casos $(37.4 \%)$ foram de padrão alveolar, $45(49.5 \%)$ foram de padrào intersticial, 3 casos $(3,3 \%)$ de padrão brônquico e 8 casos $(8.8 \%)$ foram considerados quadros mistos sem um padrão único predominante. O padrão pulmonar vascular não foi observado neste estudo. Concluímos que as doenças pulmonares intersticiais seguidas pelas doenças alveolares foram as mais freqüentes. Os padròes alveolares observados foram correlacionados principalmente a broncopneumonias, edemas, hemorragias e contusões pulmonares. Dentre os casos de lesão pulmonar intersticial, o padrão difuso foi observado em 9 casos $(9.9 \%)$, sendo estes correlacionados a pneumonias intersticiais, edema e contusões pulmonares. Em 36 exames $(39.6 \%)$ observamos padrão intersticial nodular sendo que este padrão é freqüentemente associado a quadros neoplásicos e principalmente a metástases pulmonares. Consideramos neste estudo que um número bastante expressivo de alterações radiográficas pulmonares foi decorrente a quadros de metástase pulmonar. 